\title{
Investigational Therapies for Ischemic Stroke: Neuroprotection and Neurorecovery
}

\author{
Preeti Sahota $\cdot$ Sean I. Savitz
}

Published online: 21 May 2011

(C) The American Society for Experimental NeuroTherapeutics, Inc. 2011

\begin{abstract}
Stroke is one of the leading causes of death and disability worldwide. Current treatment strategies for ischemic stroke primarily focus on reducing the size of ischemic damage and rescuing dying cells early after occurrence. To date, intravenous recombinant tissue plasminogen activator is the only United States Food and Drug Administration approved therapy for acute ischemic stroke, but its use is limited by a narrow therapeutic window. The pathophysiology of stroke is complex and it involves excitotoxicity mechanisms, inflammatory pathways, oxidative damage, ionic imbalances, apoptosis, angiogenesis, neuroprotection, and neurorestoration. Regeneration of the brain after damage is still active days and even weeks after a stroke occurs, which might provide a second window for treatment. A huge number of neuroprotective agents have been designed to interrupt the ischemic cascade, but therapeutic trials of these agents have yet to show consistent benefit, despite successful preceding animal studies. Several agents of great promise are currently in the middle to late stages of the clinical trial setting and may emerge in routine practice in the near future. In this review, we highlight select pharmacologic and cell-based therapies that are currently in the clinical trial stage for stroke.
\end{abstract}

Electronic supplementary material The online version of this article (doi:10.1007/s13311-011-0040-6) contains supplementary material, which is available to authorized users.

P. Sahota $\cdot$ S. I. Savitz $(\bowtie)$

Department of Neurology,

University of Texas Medical School at Houston,

Houston, TX 77030, USA

e-mail: sean.i.savitz@uth.tmc.edu
Keywords Stroke - Cerebral ischemia - Neuroprotection . Neurorecovery; · Cell-based therapy · Pharmacologic therapy

\section{Introduction}

The only treatment for ischemic stroke, recombinant tissue plasminogen activator (rt-PA), focuses on recanalization to reduce the size of ischemic damage [1, 2]. There are at least two other major categories of investigational therapies that are currently under development for ischemic stroke, which are: 1) neuroprotection and 2) neurorecovery approaches. Cerebral ischemia activates a cascade of biochemical events that ultimately lead to the death of brain cells. More than 20 years of research has focused on discovering and developing so-called neuroprotective agents that might intervene in this ischemic cascade. Thus far, no protective agent has been shown to improve outcome in phase III clinical trials, but newer approaches continue to be investigated. After the infarct has developed, recovery of motor and cognitive function occurs to a variable degree through a number of pathways, including recruitment of existing but latent connections and development of new neurons and neural connections [3-7]. The regeneration of the brain after damage is still active days and even weeks after the stroke occurs, which might provide a second window for treatment [8]. Therefore, neurorecovery approaches are being developed that promote the repair of disrupted neural networks during the subacute and chronic phase of ischemic stroke [9]. This review covers pharmacological and cell-based strategies under investigation that fall into the category of neuroprotection, neurorecovery, or both. We focus our discussion on neuroprotective agents that are currently in clinical trials. 


\section{Neuroprotection}

\section{Hypothermia}

The impact of cold temperature on the human body has been studied by clinicians for long time. Hippocrates [10] advocated packing bleeding patients in snow and ice. Approximately 180 years ago, Baron Dominique-Jean Larrey was the first to realize that tissues could recover from low temperatures. He realized that rapid rewarming of hypothermic tissues led to more severe frostbite and gangrene, and hence developed rewarming strategies to salvage very cold body tissues $[11,12]$. Hypothermia is one of most promising treatment strategies for acute ischemic stroke. Mild hypothermia is an established neuroprotectant in the laboratory, showing remarkable and consistent effects across multiple laboratories and models of brain injury. It has been shown to improve neurological outcome in comatose survivors of cardiac arrest and neonatal hypoxia ischemia, and it is increasingly being used by many centers for these conditions [13-15]. However, hypothermia remains poorly understood as a therapy for stroke.

\section{Mechanisms of Neuroprotective Effects of Hypothermia: Supportive Animal Data}

Animal models of focal or global cerebral ischemia have suggested that hypothermia confers protection against ischemia or reperfusion injury through multiple mechanisms. Brain protection from hypothermia is associated with preserved metabolic stores, reduced blood flow, prevention of glutamate release, reduced generation of excitotoxins, improved cellular ion handling and $\mathrm{pH}$ balance, decreased inflammation, decreased apoptosis, and alterations in gene expression [16-24]. Activation of peripheral leukocytes and brain resident microglia also occurs after brain injury, and mild hypothermia has been shown to inhibit this activation $[25,26]$. Suppression of this activation could be explained by the observation that hypothermia inhibits the pro-inflammatory transcription factor NFkB [27-29]. Hypothermia also appears to upregulate cell survival pathways, such as activating the Akt pathway [30, $31]$ and increasing trophic factor expression [32, 33]. In a systematic review and meta-analysis of animal studies of focal cerebral ischemia, including data obtained from a total of 3,353 animals, hypothermia reduced infarct size by $44 \%$ (95\% confidence interval, 40-47\%) [34]. Thus, hypothermia has the potential to affect multiple aspects of cell physiology.

Hypothermia in Ischemic Stroke: Current Clinical Literature

A few clinical studies of mild hypothermia in acute ischemic stroke have been published or are ongoing [35,
36], and have collectively shown feasibilty, although not completely without complications [37-45] (Table 1). A significant challenge is that stroke patients are generally awake (not having endotracheal intubation), and the affected vessel often remains occluded for days or indefinitely in the absence of reperfusion therapies. Similar to what has been encountered in the cardiac arrest and brain injury studies, attaining and maintaining the target temperature is challenging. Another issue is the rebound increased intracranial pressure experienced during rewarming, a phenomenon not well studied in laboratory models [37]. A few clinical studies have used intravascular cooling devices to cool acute stroke patients. In the Cooling for Acute ischemic Brain Damage (i.e., COOL-AID) trial, a randomized pilot feasibility study using endovascular device, most patients tolerated hypothermia, and the clinical outcomes were similar in both the hypothermia group as well as in standard medical management group. There was a suggestion of reduced lesion growth on diffusion-weighted imaging in patients receiving hypothermia. The International Cooling in the Treatment of Stroke (ICTuS) trial [42], nonrandomized clinical trial using a different intravascular cooling device, also addressed administration of rt-PA to improve chances of recanalization followed by hypothermia. The Intravenous Thrombolysis Plus Hypothermia for Acute Treatment of Ischemic Stroke (ICTuS-L) study [43], a randomized multicenter trial of hypothermia and rt-PA in acute stroke patients, is the most recent study of catheter-based cooling. In this study, a total of 58 patients were randomized, 30 to normothermia and 28 to hypothermia at $33^{\circ} \mathrm{C}$ for 24 hours. In the hypothermia group, 24 patients received rt-PA. Cooling was well tolerated and did not affect the occurrence or severity of brain hemorrhage in patients given rt-PA. There were no differences in 90-day outcomes, although the study was not powered to determine efficacy. Pneumonia was the main adverse event that occurred more frequently in cooled patients. Overall, these patients tolerated cooling well, and the incidence of cerebral hemorrhage did not increase. Thus, hypothermia is feasible in ischemic stroke patients, but its benefit is not yet known.

Optimal Cooling Hypothermia can be classified based on the depth of cooling from a normal body temperature of 37 to $38^{\circ} \mathrm{C}$ : mild $\left(32-35^{\circ} \mathrm{C}\right)$, moderate $\left(28-32^{\circ} \mathrm{C}\right)$, and deep hypothermia $\left(<28^{\circ} \mathrm{C}\right)$. Animal studies of stroke and hypothermia have demonstrated that even modest cooling has considerable potential as a neuroprotective strategy, and the extent of neuroprotection is similar whether the temperature is reduced to $34^{\circ} \mathrm{C}$ or $25^{\circ} \mathrm{C}$. The depth of cooling seems to be a less critical factor, provided that brain temperature is lowered below $35^{\circ} \mathrm{C}$. Side effects of hypothermia appear to occur more frequently with each degree of Celsius reduction in temperature. Temperature 


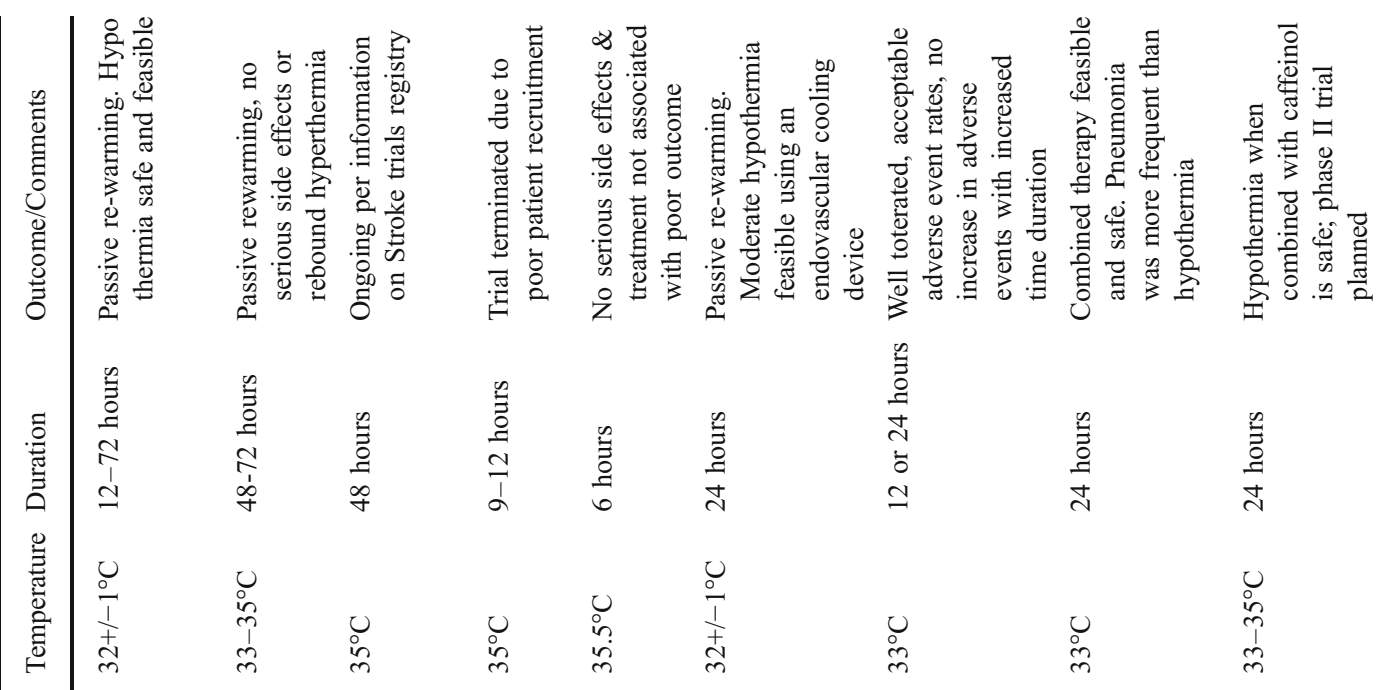

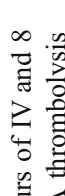

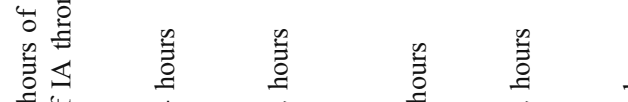

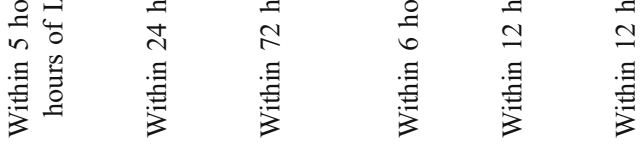

章

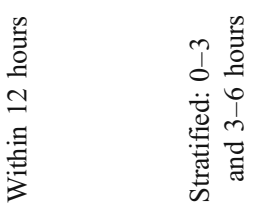

言

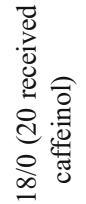

$\stackrel{\infty}{\rightarrow}$

인

:

(

$\stackrel{0}{\circ} \quad \frac{1}{\infty} \stackrel{\circ}{\stackrel{2}{=}} \frac{\pi}{\infty}$

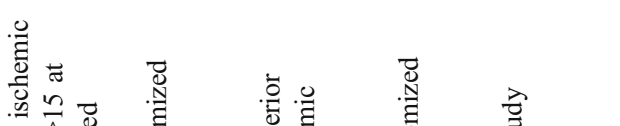

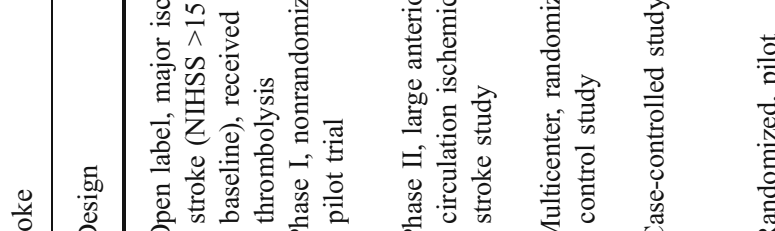

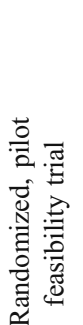

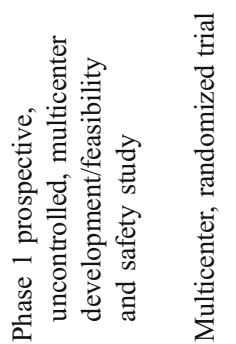

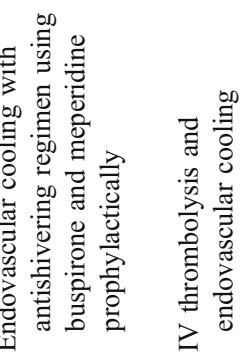

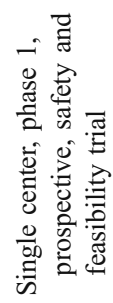

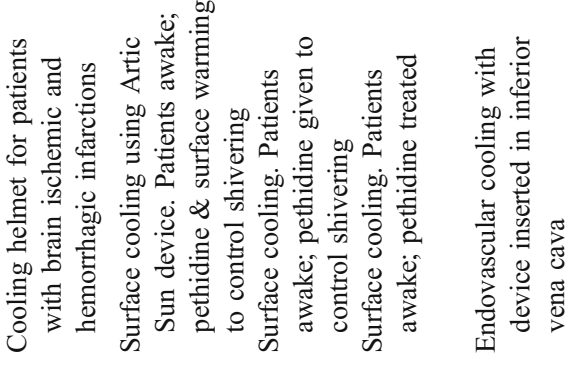

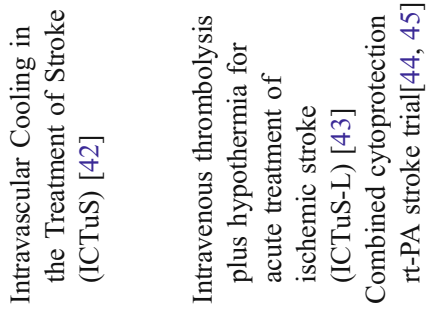

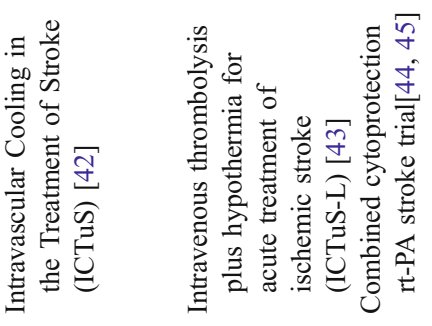

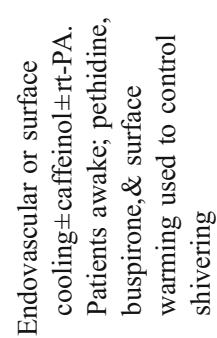

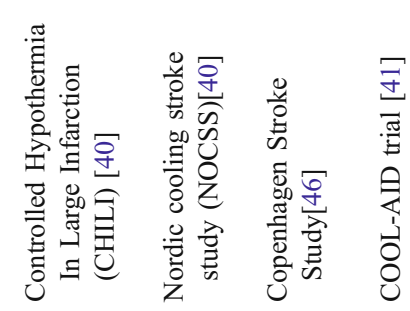

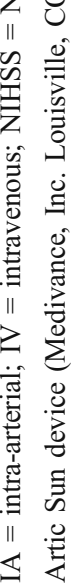


reductions to $35^{\circ} \mathrm{C}$ have been shown to be feasible and safe with surface cooling in awake, acute ischemic stroke patients, in combination with meperidine to treat shivering [46]. The ICTuS-L trial [43] found intravascular cooling to $33^{\circ} \mathrm{C}$ in combination with intravascular thrombolysis safe and feasible.

\section{Future Directions}

Currently, hypothermia suffers from lack of technological development, and cooling technologies are in their infancy. Current technologies provide reasonable control of body temperature, but they may cool patients too slowly to optimally target intra-ischemic treatment window. A phase $2 / 3$ efficacy trial of mild endovascular cooling has just begun to date. Focal cooling is likely to be advantageous for stroke because it seems likely that a reduction of local tissue temperature is all that is required to confer protection and minimize the time to target temperature and adverse effects, such as shivering and infection. A few preclinical studies have shown that neurotensin and its analogs, 3iodothyronamine and hydrogen sulfide, can all decrease body temperature to the depth and for durations previously shown to be neuroprotective in animal models [47].

\section{Albumin}

Human serum albumin is a major component of plasma, cerebrospinal fluid, and interstitial fluid, and an important circulating carrier, which is synthesized mainly in the liver. The multiple beneficial effects of higher serum albumin levels include binding to free fatty acids, metabolites and drugs, providing energy to neurons for metabolism and repairing injured neurons, supporting endothelial cell function by inhibiting apoptosis, reversal of blood-element aggregation, and exerting antioxidant effects [48-50].

\section{Mechanisms of Neuroprotective Effects of Albumin Therapy: Supportive Animal Data}

The neuroprotective effects of human albumin have been demonstrated in models of acute cerebral ischemia, including transient and permanent middle cerebral artery occlusion models or global ischemia models [48, 51-54]. It has also been shown to improve cerebral perfusion $[54,55]$, to normalize changes in diffusion-weighted magnetic resonance imaging [53], to reverse postischemic microvascular stasis [56], and to contribute to the systemic mobilization and supply of free fatty acids to the postischemic brain [57]. These studies used albumin doses of $1.25 \mathrm{~g} / \mathrm{kg}$ to $2.5 \mathrm{~g} / \mathrm{kg}$ and found them to be markedly neuroprotective, with a therapeutic window of 4 to 5 hours [48]. The potential ability of albumin to maintain the permeability of microvasculature has been suggested as the pathophysiological basis for its possible synergistic effect with rt-PA. Several specific albumin-binding sites are expressed by microvascular endothelial cells on their surface [58-60]. Albumin binds to endothelial glycocalyx and maintains the normal permeability of microvessel walls, serving as a carrier for various molecules through its capability of transcytosis across endothelium [59, 61, 62]. Tang et al. [63] demonstrated significantly reduced blood brain barrier permeability in a transient focal ischemia rat model when treated with rt-PA along with albumin, and hence significantly attenuating deleterious effects of rt-PA. Albumin is also an important inhibitor of platelet aggregation [64-66]. Albumin also increases the production of the anti-aggregatory prostaglandin (PGD2) from cyclic endoperoxides [65]. The use of albumin also binds plateletactivating factor with high affinity [66, 67], and decreases platelet-activating factor induced responses in platelets [68]. The coating of thrombogenic surfaces with S-nitrosylated albumin reduces platelet adhesion and aggregation, which is an effect attributable to both the direct antiplatelet actions of nitric oxide and the anti-adhesive properties of albumin itself [64]. Another protective mechanisms exerted by high-dose albumin infusion in ischemic stroke may be scavenging of the accumulating lysophosphatidylcholine and preventing its pro-inflammatory and proapoptotic effects [52, 69].

Clinical Literature The Albumin in Acute Stroke (ALIAS) pilot clinical trial [70] found that $25 \%$ human albumin (in doses ranging up to $2.05 \mathrm{~g} / \mathrm{kg}$ ) was well tolerated by patients with acute ischemic stroke without major doselimiting complications, and rt-PA therapy did not affect the safety profile of albumin. Based on these results, a large, randomized, double-blind, placebo-controlled, multicenter clinical trial designed to ascertain the therapeutic efficacy of albumin in acute ischemic stroke within 5 hours from onset is currently ongoing to date.

\section{Magnesium}

Magnesium is an endogenous calcium antagonist that regulates vascular tone, blood pressure, and cell membrane function. There is extensive experience with magnesium use, largely in pre-eclampsia/eclampsia, which confirms its safety and tolerability. There are a number of potential mechanisms by which magnesium may act, including increased regional blood flow to ischemic brain areas [71], nonspecific antagonism of all subtypes of voltagesensitive calcium channel [72], noncompetitive blockade of the N-methyl-D-aspartate acid subclass of glutamate receptor [73-78], presynaptic glutamate release inhibition [79- 
82], potentiation of adenosine action, enhanced recovery of cellular energy metabolism after ischemia [83, 84], and improved mitochondrial calcium buffering [85]. The neuroprotective effects of magnesium have been found in many models of ischemic cerebral damage [86-88]. In permanent or transient middle cerebral artery occlusion models in rodents, systemically administered magnesium reduced infarct volume [87, 88]. In embolic middle cerebral artery occlusion, magnesium significantly reduced infarct volume and improved neurological outcome even when given 6 hours after onset of ischemia [78]. A number of small clinical trials of magnesium that were undertaken, initially established its safety for use in acute stroke [89, 90]. Several of these small pilot trials in stroke have reported reduced proportions of magnesium-treated patients being dead or disabled at 3 to 6 months [89-94]. The odds ratio for death or disability in a systematic review of these pilot trials was 0.73 , but with a wide $95 \%$ confidence limit $(0.38$, 1.41) [95]. However, the Intravenous Magnesium Efficacy in Stroke (IMAGES) trial using a 12-hour treatment window found magnesium to be largely ineffective, with a benefit in lacunar strokes only $[94,96]$. In the Field Administration of Stroke Therapy-Magnesium (FASTMAG) pilot trial [97], no adverse events related to field administration of magnesium were observed. Because of the concerns that the Intravenous Magnesium Efficacy in Stroke (IMAGES) trial applied an unrealistically long enrollment period, the FAST-MAG efficacy trial was established and is ongoing [98]. The FAST-MAG trial uses pre-hospital randomization and treatment in the field. More than 1000 patients have been randomized to date, with more than $70 \%$ patients treated within the first hour of symptoms, which is by far the fastest treatment in any stroke trial ever accomplished. Table 2 summarizes the clinical trials of magnesium in ischemic stroke.

\section{Neuroprotection and Neurorecovery}

\section{Granulocyte Colony Stimulating Factor}

Hematopoietic growth factors, also known as colony stimulating factors, modulate and recruit the lineagespecific differentiation of bone marrow stem cells leading to generation of circulating red cells, white cells, and platelets, and their mobilization to peripheral blood. Interestingly, data from experimental studies suggest that colony stimulating factors could improve stroke outcome by reducing stroke damage and improving post-stroke brain repair [99]. As an example, granulocyte colony stimulating factor (G-CSF) is a growth factor of approximately $20 \mathrm{kDa}$ that acts on hematopoietic $\mathrm{CD} 34^{+}$stem cells to regulate neutrophil progenitor proliferation and differentiation, and is routinely used for the treatment of chemotherapy-induced neutropenia, or for the purpose of mobilizing and harvesting peripheral blood stem cells for subsequent autologous or allogenic infusion. In rat and mice models of ischemic stroke, G-CSF reduces stroke lesion volume at various doses [100], even in the presence of thrombolysis [101-103]. G-CSF protects neurons against glutamate-induced excitotoxicity [100], induces functional recovery by stimulating neuronal progenitor cells [104, 105], and promotes angiogenesis [105-107] and neurogenesis [105, 107, 108]. G-CSF also reduces inflammatory responses by suppressing inducible nitric oxide synthase and other inflammatory mediators, such as interleukin 1- $\beta$ [109-111], as well as stem cell mobilization to the brain [105]. G-CSF is released in response to cerebral ischemia and its effects are probably mediated by a special neuronal G-CSF receptor, because it passes even the intact blood brain barrier, and therefore reaches injured brain regions [100, 108]. However, G-CSF has also been reported to lead to impaired behavioral function [112], and may be of no benefit when given in the chronic phase of stroke [113] or in global ischemic models [114].

The promising results in animal models led to the implementation of phase I/II randomized clinical trials [115-119] as summarized in Table 3. Together, these trials show that G-CSF was well tolerated and appeared to be safe, and significantly increased white cell counts. Larger clinical trials aiming at confirming safety and demonstrating efficacy of G-CSF are underway. Data from these completed and ongoing trials will inform whether larger phase III trials of G-CSF are warranted.

\section{Citicoline}

Citicoline is a naturally occurring endogenous compound that was originally identified as the key intermediary in the biosynthesis of phosphatidylcholine by Kennedy [119] in 1956. Also known as CDP-Choline, citicoline is an essential precursor in the synthesis of phosphatidylcholine, a key cell membrane phospholipid. Citicoline has been increasingly recognized as a neuroprotectant that may act both in early and late stages of ischemic damage, resulting in a plethora of experimental and clinical trials assessing safety and efficacy of its use as a treatment for stroke. Citicoline neuroprotective effects may occur through its ability to improve phosphatidyl choline synthesis in the injured brain [120]. Citicoline stabilizes and repairs membranes [121]; favors the synthesis of nucleic acids, proteins, acetylcholine, and other neurotransmitters; decreases free radical formation; inhibits free fatty acid release [122, 123]; and has anti-apoptotic effects [124]. Due to these effects, citicoline may simultaneously inhibit different steps of the ischemic cascade, thus protecting the targets against early and delayed mechanisms responsible 


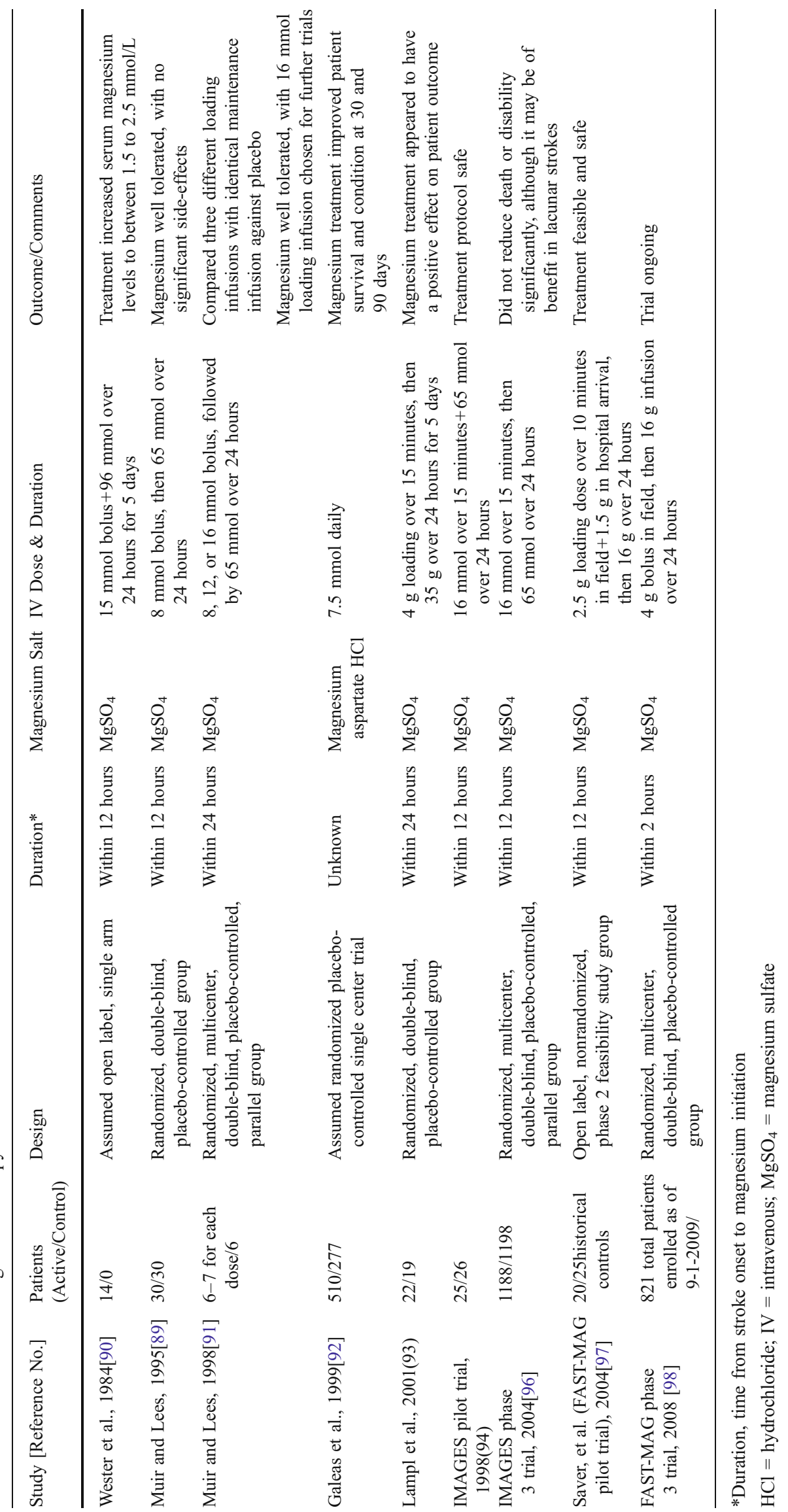




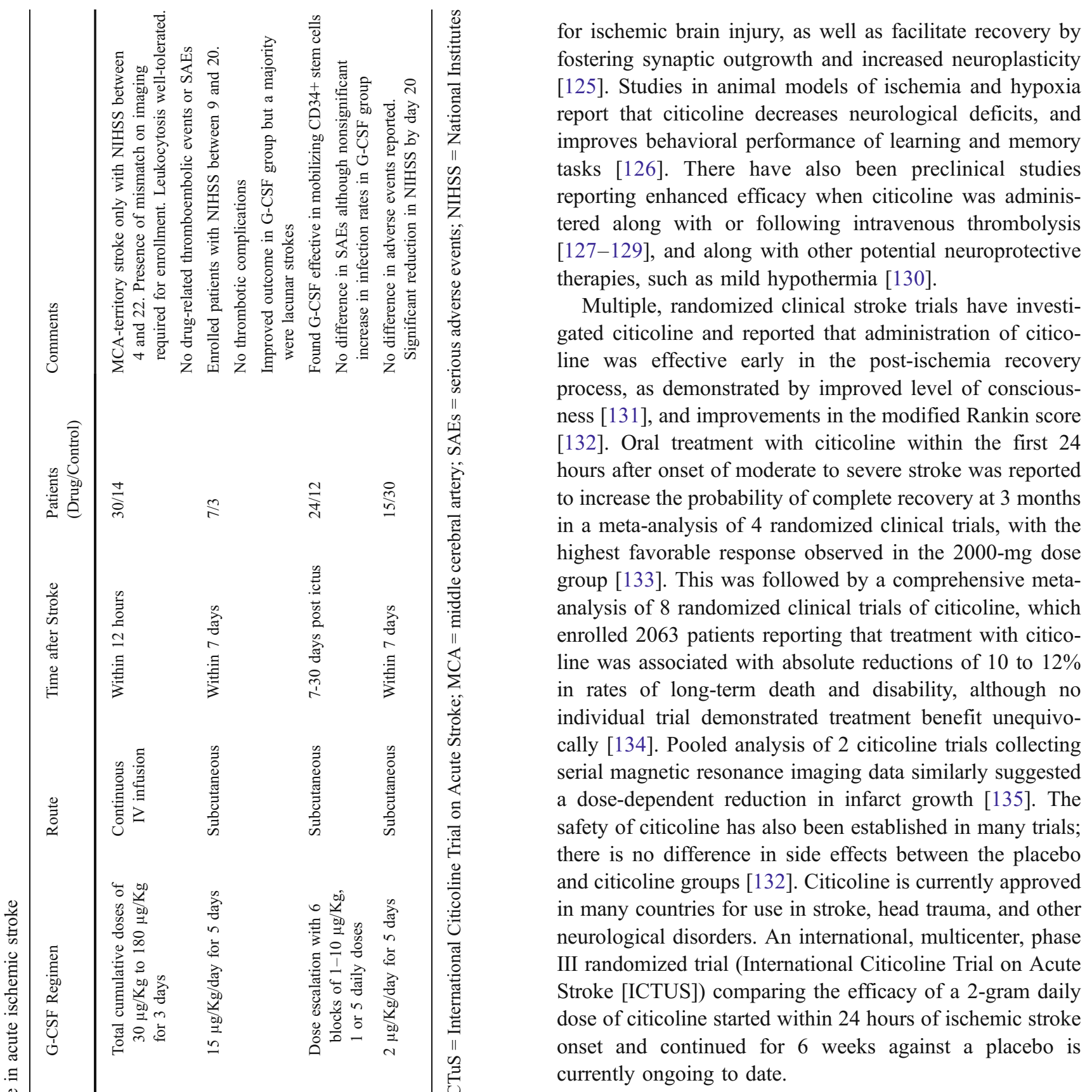

Neurorepair and Neurorestoration: Cell-Based Therapies

The adult brain responds to acute injuries, such as stroke, by inducing neural progenitor proliferation, which might be an endogenous attempt at self-repair, a process that is active for days and even weeks after a stroke and is altered by several endogenous and exogenous modulators. Functional recovery may occur in a small brain injury using rehabilitation measures, but for large ischemic strokes the restoration may require new synaptic connections within and away from the damaged tissue. Functional neuroimaging has demonstrated changes in a number of features of brain 
function after stroke, including global derangement in brain function and behavior in the initial hours/days, followed by a period of growth characterized by demonstrable structural and functional changes in both the ipsilateral and contralateral hemispheres that last several weeks, that is finally followed by pruning and reduction in functional over-activation as well as establishment of a static pattern of brain activity and behavior. This growth-related period may be a key target for certain restorative therapies during the early phase of acute stroke [136]. Hence, the treatment strategies targeting the prospects of repairing the neuron system, either by modulating endogenous neurogenesis or using exogenous stem cells to replace the lost cells or support the remaining cells in the post-ischemic brain, provide a unique approach for brain repair and restoration of function after a devastating stroke. The potential application for stem cell therapy is vast, but development for its use in ischemic stroke is still in its infancy. Despite a limited understanding of their mechanism of action, a plethora of experimental and clinical trials assessing their use in stroke have been already performed.

\section{Cell Types and Their Sources for Stroke Therapy}

Stem cells have the capacity to self-renew and differentiate into different cell types, including neurons, astrocytes, and endothelial cells. A number of cell sources for stem cell transplantation are available, and these can be categorized into several dimensions: exogenous or endogenous sources of cells; embryonic, fetal, or adult derivation; neural or nonneural origin; and pluripotential, which can divide indefinitely; or multipotential, which usually regenerate their "own tissue" but have the ability to trans-differentiate into other tissue cell types. The cell types that have been tested in preclinical transplantation studies in the stroke model are summarized in Table 4.

\section{Embryonic Stem Cells}

Fetal tissue has been the major source of cell transplantation in animal models of stroke. Embryonic stem cells (ESCs) are self-renewing and multipotent cells with unlimited expandability derived from the inner cell mass of the pre-implantation blastocyst [137]. The potential drawback of these cells is that they tend to develop a heterogeneous mix of neural precursors and differentiated neurons [138], and have potential for malignant transformation producing teratomas and highly malignant teratocarcinomas $[139,140]$. Due to this potential risk, there have not been extensive reports of transplanting undifferentiated ESCs in stroke animals [141, 142]. Xenologous transplantation has been suggested to exert a tumor-suppressive effect on ESCs [141]. Another possible solution to overcome these drawbacks is to differentiate ESCs in vitro first, which seems to greatly reduce their tumorigenic potential [142]. Recent developments in the induction of pluripotent stem cells from somatic adult cells provide a tremendous opportunity for this field [143-145] to consider an alternative source of pluroipotent cells rather than ESCs. The transplantation of induced pluripotent cells has not been studied in stroke, but if this technique works it would provide the advantage of both generating autologous and specifically engineered stem cells for an individual patient.

\section{Neural Stem Cells}

Several studies have explored the possibility of transplanting neural stem cells (NSCs) derived from the subventricular zone in animal stroke models and have reported successful differentiation of these cells into different neurons and glial cell types, with their robust migration to the ischemic area and resultant improvement in functional behavioral tests [146-148]. An enriched environment appears to improve NSCs migration and functional recovery [149]. These cells can be genetically modified to express certain genes that may facilitate the regeneration process [150]. As an alternative, immortalized neuronal precursor cell lines derived from cultured adult neural tissue offer a ready and unlimited source of cells, thereby reducing ethical concerns in obtaining aborted fetal tissue. Malignant transformation following therapeutic transplantation of this cell type is a key concern for this approach.

\section{Stem Cells Derived from Blood and Bone Marrow}

Bone marrow-derived stem cells (BMSCs), umbilical cord blood, and peripheral blood stem cells are alternative sources of stem cells, and their use carries less ethical concerns when transplanted in an autologous manner. Bone marrow and umbilical cord blood are composed of multiple cell types containing hematopoietic and endothelial CD $34^{+}$precursor cells and nonhematopoietic mesenchymal stromal (MSC) or CD34- cells. A small percentage of BMSCs are multipotent, with the remaining representing more differentiated committed cells [151]. BMSCs have been shown to improve outcome in experimental models of stroke $[152,153]$ and preserve cognitive function; behavioral improvement has been demonstrated with intracarotid transplantation of MSC [154] and CD133+ cells in rat stroke models [155], as well as with intravenous administration of umbilical cord stem cells [156, 157]. Autologous BMSCs have been safely harvested from rodents after stroke and documented to migrate to the peri-infarct area, enhance recovery, and modulate the post-ischemic inflammatory response. [158] There are several bone marrow-derived cell 
Table 4 A representative sampling of different cell types in animal models of ischemic stroke

\begin{tabular}{|c|c|c|c|c|c|}
\hline Cell Source & $\begin{array}{l}\text { Stroke Model } \\
\text { Studied }\end{array}$ & $\begin{array}{l}\text { Transplant } \\
\text { Approach }\end{array}$ & Delivery Time & Outcome & $\begin{array}{l}\text { References } \\
\text { Numbers }\end{array}$ \\
\hline \multirow[t]{2}{*}{ Rat SVZ NSCs } & $\begin{array}{l}\text { Rat embolic } \\
\text { MCAO }\end{array}$ & Cisterna magna & 2 days & $\begin{array}{l}\text { Improved sensorimotor function. } \\
\text { Angiogenesis measured by MRI }\end{array}$ & $147-149$ \\
\hline & Rat MCAO & Intracerebral & 3 hours & Recovery in limb placing and cylinder tests & 151 \\
\hline Mouse SVZ NSCs & Rat MCAO & Intracerebral & 7 days & $\begin{array}{l}\text { Recovery in cylinder tests only in } \\
\text { enriched environment }\end{array}$ & 150 \\
\hline Embryonic stem cells & $\begin{array}{l}\text { Mouse/Rat } \\
\text { MCAO }\end{array}$ & Intracerebral & 2 weeks & $\begin{array}{l}\text { Neuron formation in rats, tumor } \\
\text { formation in mouse }\end{array}$ & 143 \\
\hline \multirow[t]{3}{*}{ Rat MSCs } & Rat MCAO & Intracerebral & 1 day & Improved sensorimotor function and NSS & 153 \\
\hline & Rat MCAO & Intravenous & 1 or 7 days & $\begin{array}{l}\text { Recovery in somatosensory behavior } \\
\text { and NSS }\end{array}$ & 154 \\
\hline & Rat MCAO & Intracarotid & 1 day & Recovery on adhesive removal test and NSS & 155 \\
\hline \multirow[t]{2}{*}{$\begin{array}{l}\text { Human umbilical cord } \\
\text { blood stem cells }\end{array}$} & Rat MCAO & $\begin{array}{l}\text { Intravenous } \\
\quad\left(\text { dose } 3 \times 10^{6} \text { cells }\right)\end{array}$ & 24 hours & Significantly improved functional recovery & 157 \\
\hline & & $\begin{array}{l}\text { Intravenous } \\
\quad\left(\text { dose } 1 \times 10^{6} \text { cells }\right)\end{array}$ & 48 hours & $\begin{array}{l}\text { Significantly improved functional recovery } \\
\text { compared to saline or RN33b NSCs }\end{array}$ & 158 \\
\hline Rat MAPCs & Rat MCAO & Intracerebral & 1 week & $\begin{array}{l}\text { Recovery on limb placement \& sticky } \\
\text { tape test }\end{array}$ & 165 \\
\hline $\begin{array}{l}\text { Human olfactory } \\
\text { ensheathing cells }\end{array}$ & Rat MCAO & Intracerebral & 1 day & Recovery on behavioral tests & 167 \\
\hline Mononuclear cells & Rat MCAO & Intra-arterial & 1 day & Recovery on behavioral tests & 198 \\
\hline
\end{tabular}

MAPCs = multipotent adult progenitor cells; $\mathrm{MCAO}=$ middle cerebral artery occlusion; $\mathrm{MRI}=$ magnetic resonance imaging; $\mathrm{MSCs}=$ marrow stromal cells; NSCs = neural stem cells; NSS = neurological severity score; SVZ = subventricular zone

types that have greater potential than normal BMSCs, such as multipotent adult progenitor cells [159], marrow isolated adult multilineage inducible cells [160], human bone marrow-derived multipotent stem cells [161], and very small embryonic-like stem cells [162]. These cells are pluripotent and can differentiate into cell types originated from mesenchymal, endodermal and ectodermal layers [163]. When tested in an in vivo stroke model, multipotent adult progenitor cells could significantly enhance functional recovery in stroke animals [164]. Human bone marrowderived multipotent stem cells have been tested in the myocardial animal model with a beneficial outcome [161]. The other bone marrow-derived pleuripotent cell types have not been tested in models of ischemic brain injury to best of our knowledge.

\section{Olfactory Ensheathing Cells}

Olfactroy ensheathing cells (OECs) are the cells ensheathing the axons of neurons in the olfactory bulb. These cells share the features of both the Schwann cells and astrocytes [165]. Recently, OECs have been tested in a stroke animal model in which they secreted trophic factors, including stromal-cell derived factor-1 alpha. Rats implanted with OECs showed improvement in both behavioral measurement and functional neuroimaging [166].

\section{Potential Mechanisms of Stem Cell-Mediated Recovery}

Multiple mechanisms have been proposed that may account for the beneficial outcome observed in cell transplantation studies.

\section{Cell Replacement}

Multiple studies in animal models of stroke have reported ability of transplanted stem cells to migrate to the ischemic brain area and differentiate into neuronal and glial phenotypes [167, 168]. Furthermore, synaptogenesis and integration into host neuronal circuits have been demonstrated in the host brain, suggesting that the cell replacement might be an achievable goal [169, 170]. However, there is now evidence that neural differentiation is not necessary for the beneficial outcome observed in many types of transplantation-based therapy [171]. Furthermore, neuroprotective effects of peripherally transplanted cells without crossing blood brain barrier have been reported [172].

\section{Trophic Factor Production}

Transplanted cells may produce trophic factors, supporting the survival of existing neurons in the peri-infarct areas [172, $173]$, as well as neurogenesis and synaptogenesis $[166,174]$. 
Angiogenesis

Transplanted cells may play an important role in enhancing neovascularization in stroke animals. Cell transplantationinduced neovascularization has been reported with BMSCs, NSCs, and cells from human blood origin [175-177].

Reduced Apoptosis and Inflammation

A decrease in cell death within peri-infarct areas has been demonstrated with intravenous administration of human stem $\left(\mathrm{CD} 34^{+}\right)$cells and via intracerebral grafting of human NSCs in ischemic stroke models $[176,178]$. It is also likely that stem cells play a pivotal role in the regulation of the inflammatory cascade by suppressing the inflammatory response via the production of cytokines and growth factors [179].

\section{Facilitating Recruitment of Endogenous NSCs}

The nonregenerative capability of the injured adult brain has been challenged in recent years and neural plasticity has been observed experimentally in both global and focal brain ischemia in animal models [180]. Under physiological conditions, the subventricular zone NSCs proliferate and migrate along the rostral migratory stream to the olfactory bulb and differentiate into granular interneurons [181]. Furthermore, newly generated neurons migrate toward ischemic boundary regions and differentiate into neurons $[182,183]$. There is evidence that, although stroke stimulates these processes, the endogenous response is not enough for recovery of brain function [184]. Transplanted cells may support the survival of newly generated neurons and glial cells by inhibiting apoptosis at injury sites [185].

\section{Clinical Trials of Cell Transplantation after Ischemic Stroke}

There have been no large-scale clinical trials of cell transplantation in stroke. In a recent Cochrane review [186] of 13 studies of stem cells in patients with ischemic stroke, the authors identified only 3 very small randomized control trials, with 2 of them still awaiting clarification, and the third trial randomized 30 patients of middle cerebral artery infarction with persistent neurological deficit 7 days after their stroke to intravenous transplantation of autologous MSCs ( $\mathrm{n}=5)$, or a control, standard of care group ( $\mathrm{n}=$ 25). This study reported a statistically nonsignificant functional improvement in treated patients at longer follow-up without adverse cell-related events, demonstrating initial evidence for feasibility in administering ex vivo cultured MSCs [187]. The completed, as well as the currently ongoing, prospective clinical studies investigating stem cell therapy for acute ischemic stroke [188-191, 199208] have been summarized in Table 5 .
Future Development of Cell-Based Products as a Potential Treatment of Stroke

Despite availability of large preclinical data suggesting potentially improved clinical outcome with stem cell use in ischemic stroke, limited clinical data exists and many questions remain unanswered. It is vital that future experimental studies are of high quality and have standardized protocols and outcome measures so that they can be fairly compared. Currently, guidelines are being formulated to guide further research into the role of cell-based therapy in both translational and basic research areas [191].

One possible advantage of treating stroke with stem cells is a potentially wide therapeutic window. The optimal time of administration post-stroke will relate to the microenvironment of the damaged area. That is, should stem cells be administered during the acute phase of stroke at a time when inflammatory responses are maximal or will delayed treatment be effective at a time when scar tissue has formed?

The ideal route of stem cell delivery is also unclear. This has been addressed in one pre-clinical study comparing intrastriatal, intra-ventricular, and intravenous administration of neural precursor cells with all routes resulting in cells targeting the lesion [192]. In contrast, another study assessing intravenous administration of human umbilical cord cells in rats did not detect any evidence of stem cells in the target lesion [176]. The implications of initial trapping of stem cells inside the lungs after intravenous administration on the route, dose, and type of cells used for stem cell therapy also needs to be further evaluated [193, 194]. If intra-cerebral administration proves to be the most effective (although this is probably fraught with more potential risks), then should cells be transplanted directly into the ischemic lesion or distant to it (reducing the chance of damaging vital structures) and relying on spontaneous stem cell migration? [141, 195, 196] Prior trials used intracerebral injections of neural-based cells directly into the peri-infarct area [191, 192], but an insufficient numbers of patients were studied to draw conclusions about safety. However, there is evolving literature that suggests a direct injection of some types of cells may not be necessary. For example, systemic administration of bone marrow-derived mononuclear cells, which are smaller than purified stem cells, such as mesenchymal stem cells, can pass through the lungs and may enhance recovery from a stroke. These studies support ongoing early stage trials to assess the safety of autologous Mononuclear cells (MNCs) in stroke patients [158, 197].

Overall, there are multiple sources of exogenous stem cells available, but the cell type that should be transplanted for a given stroke type and size is undetermined. Endogenous stem cell treatment is an attractive alternative, removing the need for immunosuppression. Recent advances offer the possibility to harvest adult terminally differentiated cells and reprogram them into stem cells $[143,145]$. Translating this technology to 


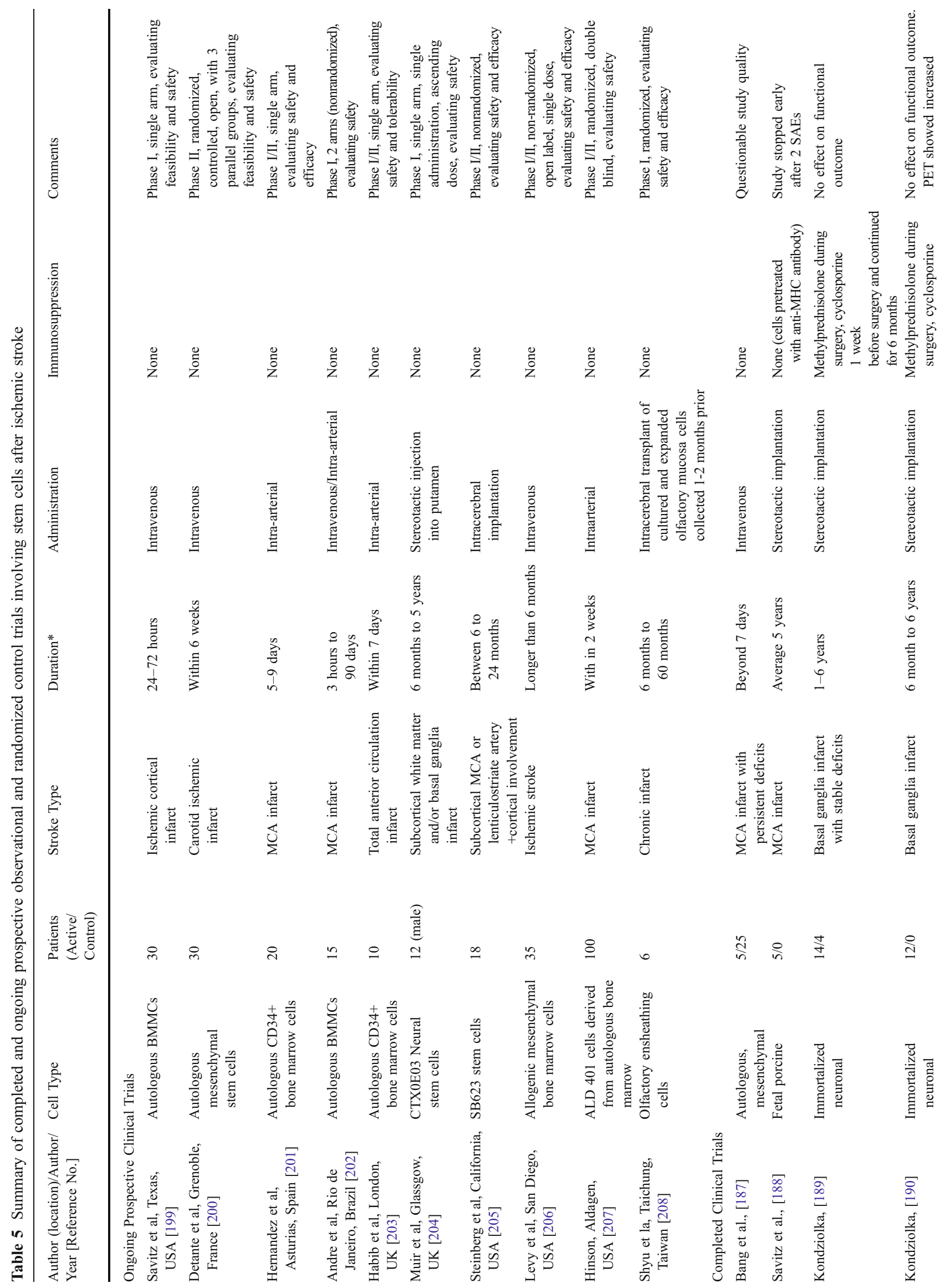


possible clinical usage would offer the advantage of generating unlimited and autologous patient specific stem cells. Developing technology that enables noninvasive tracking and monitoring of NSCs and other types of transplanted cells in vivo would greatly facilitate research in this area.

\section{Summary}

Current treatment strategies in acute ischemic stroke are vessel and blood based. Brain-based therapies, including neuroprotection through blocking the cellular, biochemical, and molecular mechanisms of ischemic injury, and neurorestoration by enhancing neuroplasticity and salvaging peri-infarct areas are potential future therapies that will increasingly complement and enhance current ischemic stroke management. Several agents of great promise are currently in the middle to late stages of clinical trial settings to date, and may emerge in routine practice in the near future.

The most promising interventions providing acute neuroprotection that are being tested in larger clinical trials include hypothermia, magnesium sulfate, citicoline, and albumin.

The most promising therapies enhancing neurorecovery in the subacute phase of stroke include G-CSF, citicoline, and cell-based therapies.

Acknowledgment Full conflict of interest disclosure is available in the electronic supplementary material for this article.

\section{References}

1. Gilman S. Pharmacological management of ischemic stroke: relevance to stem cell therapy. Exp Neurol 2006;199:28-36.

2. Goldstein LB. Acute ischemic stroke treatment in 2007. Circulation 2007;116:1504-1514.

3. Jacobs KM, Donoghue JP. Reshaping the cortical motor map by unmasking latent intracortical connections. Science 1991;251:944-947.

4. Carmichael ST, Chesselet MF. Synchronous neuronal activity is a signal for axonal sprouting after cortical lesions in the adult. $\mathrm{J}$ Neurosci 2002;22:6062-6070.

5. Bliss TV, Collingridge GL. A synaptic model of memory: longterm potentiation in the hippocampus. Nature 1993;361:31-39.

6. Pantano P, Baron JC, Samson Y, Bousser MG, Derouesne C, Comar D. Crossed cerebellar diaschisis. Further studies. Brain 1986;109:677-694.

7. Jin K, Minami M, Lan JQ, et al. Neurogenesis in dentate subgranular zone and rostral subventricular zone after focal cerebral ischemia in the rat. Proc Natl Acad Sci USA 2001;98:4710-4715.

8. Thored P, Arvidsson A, Cacci E, et al. Persistent production of neurons from adult stem cells during recovery after stroke. Stem cells 2006;24:739-747.

9. Abe K. Therapeutic potential of neurotrophic factors and neural stem cells against ischemic brain injury. J Cereb Blood Flow Metab 2000;20:1393-1408. 
10. Hippocrates. The genuine works of Hippocrates. Printed for the Syndenham Soc. New York: William Wood, 2000.

11. Remba SJ, Varon J, Rivera A, et al. Dominique-Jean Larry: the effects of therapeutic hypothermia and the first ambulance. Resuscitation 2010;81:268-271.

12. O'Sullivan ST, O'Shaughnessy M, O'Connor TPF. Baron Larrey and cold injury during the campaigns of Napoleon. Ann Plast Surg 1995;34:446-449.

13. Group THACAS. Mild hypothermia to improve the neurological outcome after cardiac arrest. N Engl J Med 2002; 346:549-556.

14. Bernard SA, Gray TW, Buist MD, et al. Treatment of comatose survivors of out-of-hospital cardiac arrest with induced hypothermia. N Engl J Med 2002;346:557-563.

15. Jacobs SE, Hunt R, Tarnow-Mordi WO, Inder TE, Davis PG. Cooling for newborns with hypoxic ischaemic encephalopathy. Cochrane Database of Systematic Reviews 2007, Issue 4. Article number: CD003311. doi:10.1002/14651858.CD003311.pub2

16. Erecinska M, Thoresen M, Silver IA. Effects of hypothermia on energy metabolism in mammalian central nervous system. J Cereb Blood Flow Metab 2003;23:513-530.

17. Polderman KH. Mechanisms of action, physiological effects, and complications of hypothermia. Crit Care Med 2009:37(suppl): S186-S202.

18. Yang D, Guo S, Zhang $\mathrm{T}$, et al. Hypothermia attenuates ischemia/reperfusion-induced endothelial cell apoptosis via alterations in apoptotic pathways and JNK signaling. FEBS Lett 2009:583:2500-2506.

19. Han HS, Yenari MA. Focal cerebral ischemia: mechanisms. In: Tisherman, Han SA, Fritz S, eds. Therapeutic hypothermia. New York, USA: Springer 2005:25-41.

20. Liu L, Yenari MA. Therapeutic hypothermia: neuroprotective mechanisms. Front Biosci 2007;12:816-825.

21. Zhao H, Steinberg GK, Sapolsky RM. General versus specific actions of mild-moderate hypothermia in attenuating cerebral ischemic damage. J Cereb Blood Flow Metab 2007;27:18791894.

22. Busto R, Globus MY, Dietrich WD, Martinez E, Veldes I, Ginsberg MD. Effect of mild hypothermia on ischemia-induced release of neurotransmitters and free fatty acids in rat brain. Stroke 1989;20:904-910.

23. Baker AJ, Zornow MH, Grae MR, Scheller MS, Skilling SR, Smullin DH. Larson AA. Hypothermia prevents ischemiainduced changes in hippocampal glycine concentrations in rabbits. Stroke 1991;22:666-673.

24. Huang R, Shuaib A, Hertz L. Glutamate uptake and glutamate content in primary cultures of mouse astrocytes during anoxia, substrate deprivation and simulated ischemia under normothermic and hypothermic conditions. Brain Res 1993;618:346-351.

25. Inamasu J, Suga S, Sato S, et al. Post-ischemic hypothermia delayed neutronphil accumulation and microgliar activation following transient global ischemia in rats. J Neuroimmunol 2000;109:66-74.

26. Wang GJ, Deng HY, Maier CM, Sun GH, Yenari MA. Mild hypothermia reduces ICAM-1 expression, neutrophil infiltration and microglia/monocyte accumulation following experimental stroke. Neuroscience 2002;114:1081-1090.

27. Yenari M, Han HS. Influence of hypothermia on post-ischemic inflammation: role of nuclear factor kappa B (NFkappaB). Neurochem Int 2006;49:164-169.

28. Han HS, Karabiyikoglu M, Kelly S, Sobel RA, Yenari MA. Mild hypothermia inhibits nuclear factor-kappa B translocation in experimental stroke. J Cereb Blood Flow Metab 2003;23:589-598.

29. Webster CM, Kelly S, Koike MA, Chock VY, Giffard RG, Yenari MA. Inflammation and NFKappaB activation is de- creased by hypothermia following global cerebral ischemia. Neurobiol Dis 2009;33:301-312.

30. Zhao H, Shimohata T, Wang JQ, et al. Akt contributes to neuroprotection by hypothermia against cerebral ischemia in rats. J Neurosci 2005;25:9794-9806.

31. Lee SM, Zhao H, Maier CM, Steinberg GK. The protective effect of early hypothermia on PTEN phosphorylation correlates with free radical inhibition in rat stroke. J Cereb Blood Flow Metab 2009;29:1589-1600.

32. Schmidt KM, Repine MJ, Hicks SD, DeFranco DB, Callaway $\mathrm{CW}$. Regional changes in glial cell line-derived neurotrophic factor after cardiac arrest and hypothermia in rats. Neurosci Lett 2004;368:135-139.

33. Vosler PS, Logue ES, Repine MJ, Callaway CW. Delayed hypothermia preferentially increases expression of brain-derived neurotrophic factor exon III in rat hippocampus after asphyxial cardiac arrest. Brain Res Mol Brain Res 2005;135:21-29.

34. Van der Worp HB, Sena ES, Donnan GA, Howells DW, Macleod MR. Hypothermia in animal models of acute ischemic stroke: a systematic review and meta-analysis. Brain 2007;130:30633074.

35. Lyden P, Krieger DW, Yenari MA, Dietrich WD. Therapeutic hypothermia for acute stroke. Int J Stroke 2006;1:9-19.

36. Hemmen TM, Lyden PD. Induced hypothermia for acute stroke. Stroke 2007;38(2 suppl.):794-799.

37. Schwab S, Georgiadis D, Berrouschot J, Schellinger PD, Graffagnino C, Mayer SA. Feasibility and safety of moderate hypothermia after massive hemispheric infarction. Stroke 2001;32:2033-2035.

38. Krieger DW, De Georgia MA, Abou-Chebl A, et al. Cooling for acute ischemic brain damage (cool aid): an open pilot study of induced hypothermia in acute ischemic stroke. Stroke 2001;32:1847-8454.

39. Wang $H$, Olivero $H$, Lanzino $G$, et al. Rapid and selective cerebral hypothermia achieved using a cooling helmet. J Neurosurg 2004;100:272-277.

40. Stroke trials registry 2010. Available at: www.strokecenter.org. Accessed on 11/4/2010.

41. De Georgia MA, Krieger DW, Abou-Chebl A et al. Cooling for acute ischemic brain damage (COOL AID): a feasibility trial of endovascular cooling. Neurology 2004;63:312-317.

42. Lyden PD, ALlgren RL, Ng K, et al. Intravascular cooling in the treatment of stroke (ICTuS): early clinical experience. J Stroke Cerebrovas Dis 2005;14:107-114.

43. Hemmen TM, Raman R, Gomez JA, et al. Intravenous thrombolysis plus hypothermia for acute treatment of ischemic stroke (ICTuS-L): final results. Stroke 2010;41:2265-2270.

44. Martin-Schild S, Barreto AD, Hallevi H, et al. Feasibility of caffeinol and hypothermia for acute ischemic stroke. Stroke 2008;39:532.

45. Martin-Schild S, Hallevi H, Shaltoni H, et al. Combined neuroprotective modalities coupled with thrombolysis in acute ischemic stroke: a pilot study of caffeinol and mild hypothermia. J Stroke Cerebrovas Dis 2009;18:86-96.

46. Kammersgaard LP, Jorgensen HS, Rungby JA, et al. Admission body temperature predicts long term mortality after acute stroke: the Coperhagen Stroke Study. Stroke 2002;33:1759-1762.

47. Yenari M, Kitagawa K, Lyden P, Perez-Pinzon M. Metabolic downregulation: a key to successful neuroprotection? Stroke 2008;39:2910-2917.

48. Belayev L, Liu Y, Zhao W, Busto R, Ginsberg MD. Human albumin therapy of acute ischemic stroke: marked neuroprotective efficacy at moderate doses and with a broad therapeutic window. Stroke 2001;32:553-560.

49. Remmers M, Schmidt-Kastner R, Belayev L, Lin B, Busto R, Ginsberg MD. Protein extravasation and cellular uptake after 
high-dose human-albumin treatment of transient focal cerebral ischemia in rats. Brain Res 1999;827:237-242.

50. Zoellner H, Höfler M, Beckmann R, et al. Serum albumin is a specific inhibitor of apoptosis in human endothelial cells J Cell Sci 1996;109:2571-2580

51. Belayev L, Alonso OF, Busto R, Zhao W, Ginsberg MD. Middle cerebral artery occlusion in the rat by intraluminal suture. Neurological and pathological evaluation of an improved model. Stroke 1996;27:1616-1622.

52. Belayev L, Busto R, Zhao W, Clemens JA, Ginsberg MD. Effect of delayed albumin hemodilution on infarction volume and brain edema after transient middle cerebral artery occlusion in rats. J Neurosurg 1997;87:595-601.

53. Belayev L, Zhao W, Pattany PM, et al. Diffusion-weighted magnetic resonance imaging confirms marked neuroprotective efficacy of albumin therapy in focal cerebral ischemia. Stroke 1998;29:2587-2599.

54. Liu Y, Belayev L, Zhao W, Busto R, Belayev A, Ginsberg MD. Neuroprotective effect of treatment with human albumin in permanent focal cerebral ischemia: histopathology and cortical perfusion studies. Eur J Pharmacol 2001;428:193-201.

55. Huh PW, Belayev L, Zhao W, Busto R, Saul I, Ginsberg MD. The effect of high-dose albumin therapy on local cerebral perfusion after transient focal cerebral ischemia in rats. Brain Res 1998;804:105-113.

56. Belayev L, Pinard E, Nallet H, et al. Albumin therapy of transient focal cerebral ischemia: in vivo analysis of dynamic microvascular responses. Stroke 2002;33:1077-1084.

57. Rodriguez de Turco EB, Belayev L, Liu Y, et al. Systemic fatty acid responses to transient focal cerebral ischemia: influence of neuroprotectant therapy with human albumin. J Neurochem 2002;83:515-524.

58. Ghitescu L, Fixman A, Simionescu M, Simionescu N. Specific binding sites for albumin restricted to plasmalemmal vesicles of continuous capillary endothelium: receptor-mediated transcytosis. J Cell Biol 1986;102:1304-1311.

59. Schnitzer JE, Oh P. Antibodies to SPARC inhibit albumin binding to SPARC, gp60, and microvascular endothelium. Am J Physiol 1992;263:H1872-H1879.

60. Schnitzer JE. gp60 is an albumin-binding glycoprotein expressed by continuous endothelium involved in albumin transcytosis. Am J Physiol 1992;262:H246-H254.

61. He P, Curry FE. Albumin modulation of capillary permeability: role of endothelial cell [Ca2+]i. Am J Physiol 1993;265:H74-H82.

62. Schnitzer JE, Sung A, Horvat R, Bravo J. Preferential interaction of albumin-binding proteins, gp30 and gp18, with conformationally modified albumins. Presence in many cells and tissues with a possible role in catabolism. J Biol Chem 1992;267:24544-24553.

63. Tang J, Li YJ, Mu J, Li Q, Yang DY, Xie P. Albumin ameliorates tissue plasminogen activator-mediated blood-brain barrier permeability and ischemic injury in rats. Neurol Res 2009;31:189-194.

64. Maalej N, Albrecht R, Loscalzo J, Folts JD. The potent platelet inhibitory effects of S-nitrosated albumin coating of artificial surfaces. J Am Coll Cardiol 1999;33:1408-14 d14.

65. Gresele P, Deckmyn H, Huybrechts E, Vermylen J. Serum albumin enhances the impairment of platelet aggregation with thromboxane synthase inhibition by increasing the formation of prostaglandin D2. Biochem Pharmacol 1984;33:2083-2088.

66. Jorgensen KA, Stoffersen E. On the inhibitory effect of albumin on platelet aggregation. Thromb Res 1980;17:13-18.

67. Ammit AJ, O'Neill C. Studies of the nature of the binding by albumin of platelet-activating factor released from cells. J Biol Chem 1997;272:18772-18778.

68. Grigoriadis G, Stewart AG. Albumin inhibits platelet-activating factor (PAF)-induced responses in platelets and macrophages: implications for the biologically active form of PAF. Br J Pharmacol 1992;107:73-77.

69. Zalewski A, Macphee CH. Role of lipoprotein-associated phospholipase A2 in atherosclerosis: biology, epidemiology, and possible therapeutic target. Arterioscler Thromb Vas Biol 2005;25:923-931.

70. Ginsberg MD, Hill MD, Palesch YY, Ryckborst KJ, Tamariz D. A dose-escalation and safety study of albumin therapy for acute ischemic stroke-I: Physiological responses and safety results. Stroke 2006;37:2100-2106.

71. Chi OZ, Pollak P, Weiss HR. Effects of magnesium sulfate and nifedipine on regional cerebral blood flow during middle cerebral artery ligation in the rat. Arch Int Pharmacodyn Therap 1990;304:196-205.

72. Iseri LT, French JH. Magnesium: nature's physiologic calcium blocker. Am Heart J 1984;108:188-193.

73. Harrison NL, Simmonds MA. Quantitative studies on some antagonists of $\mathrm{N}$-methyl D-aspartate in slices of rat cerebral cortex. Br J Pharmacol 1985;84:381-391.

74. Schmidt CJ, Taylor VL. Release of $[3 \mathrm{H}]$ norepinephrine from rat hippocampal slices by N-methyl-D-aspartate: comparison of the inhibitory effects of Mg21 and MK-801. Eur J Pharmacol 1988;156:111-120.

75. Nowak L, Bregestovski P, Ascher P, Herbet A, Prochiantz A. Magnesium gates glutamate-activated channels in mouse central neurones. Nature 1984;307:462-465.

76. Ascher P, Nowak L. The role of divalent cations in the N-methylDaspartate responses of mouse central neurones in culture. J Physiol (Lond). 1988;399:247-266.

77. Mori H, Masaki H, Yamakura T, Mishina M. Identification by mutagenesis of a Mg21-block site of the NMDA receptor channel. Nature 1992;358:673-675.

78. Yang Y, Li Q, Ahmad F, Shuaib A. Survival and histological evaluation of therapeutic window of post-ischemia treatment with magnesium sulfate in embolic stroke model of rat. Neurosci Lett 2000;285:119-22.

79. Smith DAS, Connick JH, Stone TW. Effect of changing extracellular levels of magnesium on spontaneous activity and glutamate release in the mouse neocortical slice. Br J Pharmacol 1989;97:475-482.

80. Bartrup JT, Stone TW. Presynaptic actions of adenosine are magnesiumdependent. Neuropharmacology 1988;27:761-763.

81. Ghribi O, Callebert J, Verrecchia C, Plotkine M, Boulu RG. Blockers of NMDA-operated channels decrease glutamate and aspartate extracellular accumulation in striatum during forebrain ischaemia in rats. Fund Clin Pharmacol 1995;9:141-146.

82. Lin JY, Chung SY, Lin MC, Cheng FC. Effects of magnesium sulfate on energy metabolites and glutamate in the cortex during focal cerebral ischemia and reperfusion in the gerbil monitored by a dual-probe microdialysis technique. Life Sci 2002;71:80311.

83. Kass IS, Cottrell JE, Chambers G. Magnesium and cobalt, not nimodipine, protect neurons against anoxic damage in the rat hippocampal slice. Anesthesiology 1988;69:710-715.

84. Schanne FAX, Gupta RK, Stanton PK. 31P-NMR study of transient ischemia in rat hippocampal slices in vitro. Biochim Biophys Acta 1993;1158:257-263.

85. Favaron M, Bernardi P. Tissue-specific modulation of the mitochondrial calcium uniporter by magnesium ions. FEBS Lett 1985;183:260-264.

86. McIntosh TK, Vink R, Yamakami I, Faden AI Magnesium protects against neurological deficit after brain injury. Brain Res 1989;482:252-260.

87. Izumi Y, Roussel S, Pinard E, Seylaz J. Reduction of infarct volume by magnesium after middle cerebral artery occlusion in rats. J Cereb Blood Flow Metab 1991;11:1025-1030. 
88. Marinov MB, Harbaugh KS, Hoopes PJ, Pikus HJ, Harbaugh RE. Neuroprotective effects of preischemia intraarterial magnesium sulfate in reversible focal cerebral ischemia. J Neurosurg 1996;85:117-124.

89. Muir KW, Lees KR. A randomized, double-blind, placebocontrolled pilot trial of intravenous magnesium sulfate in acute stroke. Stroke 1995;26:1183-1188.

90. Wester PO, Asplund K, Eriksson S, Hagg E, Lithner F, Strand T. Infusion of magnesium in patients with acute brain infarction. Acta Neurol Scand 1984;70:143. Abstract.

91. Muir KW, Lees KR. Dose optimization of intravenous magnesium sulfate after acute stroke. Stroke 1998;29:918-923.

92. Galeas T, C'ontos T, Exarhos P, Galea V, Valotasiou B. The role of magnesium $(\mathrm{Mg})$ a natural calcium $(\mathrm{Ca})$ antagonist in the treatment of acute ischemic stroke. Cerebrovasc Dis 1999;9 (Suppl):102. Abstract.

93. Lampl Y, Gilad R, Geva D, Eshel Y, Sadeh M. Intravenous administration of magnesium sulfate in acute stroke: a randomized double-blind study. Clin Neuropharmacol 2001;24:11-15.

94. IMAGES Study Group, Bradford APJ, Muir KW, Lees KR. IMAGES pilot study of intravenous magnesium in acute stroke. Cerebrovasc Dis 1998;8:86. Abstract.

95. Muir KW, Lees KR. Excitatory amino acid antagonists for acute stroke. Cochrane Database of Systematic Reviews 2003, Issue 3. Art. No.: CD001244. doi:10.1002/14651858. CD001244.

96. Intravenous Magnesium Efficacy in Stroke (IMAGES) Study Investigators. Magnesium for acute stroke (IMAGES trial): randomised controlled trial. Lancet 2004;363:439-445.

97. Saver JL, Kidwell C, Eckstein M, Starkman S. Prehospital neuroprotective therapy for acute stroke: results of the field administration of stroke therapy-magnesium (FAST-MAG) pilot trial. Stroke 2004;35:e106-e108.

98. The Field Administration of Stroke Therapy-magnesium phase 3 clinical trial. 2008. Available at: www.fastmag.info. Accessed on $11 / 4 / 2010$

99. Sprigg N, Bath P. Pharmacological enhancement of recovery from stroke. Curr Med Literature Stroke Rev 2005; 8:33-39.

100. Schäbitz WR, Kollmar R, Schwaninger M, et al. Neuroprotective effect of granulocyte colony-stimulating factor after focal cerebral ischemia. Stroke 2003;34:745-751.

101. Kollmar R, Henninger N, Urbanek C, Schäbitz W, Schneider A, Schwab S. Effects of G-CSF in combination with rt-PA after experimental thromboembolic stroke. Akt Neurol 2004;31:S1, V88.

102. Kollmar R, Henninger N, Urbanek C, Schwab S. G-CSF and rtPA for the treatment of experimental embolic stroke. Cerebrovasc Dis 2007;23(suppl 2):A9.

103. Kollmar R, Henninger N, Urbanek C, Schwab S. G-CSF, rt-PA and combination therapy after experimental thromboembolic stroke. Exp Transl Stroke Med 2010;14:2-9.

104. Gibson CL, Bath PM, Murphy SP. G-CSF reduces infarct volume and improves functional outcome after transient focal cerebral ischemia in mice. $\mathrm{J}$ Cereb Blood Flow Metab 2005;25:431-439.

105. Shyu WC, Lin SZ, Yang HI, et al. Functional recovery of stroke rats induced by granulocyte colony-stimulating factor-stimulated stem cells. Circulation 2004;110:1847-1854.

106. Lee ST, Chu K, Jung KH, et al. Granulocyte colony-stimulating factor enhances angiogenesis after focal cerebral ischemia. Brain Res 2005;1058:120-128.

107. Sehara Y, Hayashi T, Deguchi K, et al. Potentiation of neurogenesis and angiogenesis by G-CSF after focal cerebral ischemia in rats. Brain Res 2007;1151:142-149.

108. Schneider A, Kruger C, Steigleder T, et al. The hematopoietic factor $\mathrm{G}-\mathrm{CSF}$ is a neuronal ligand that counteracts programmed cell death and drives neurogenesis. J Clin Invest 2005;115:20832098.

109. Komine-Kobayashi M, Zhang N, Liu M, et al. Neuroprotective effect of recombinant human granulocyte colony-stimulating factor intransient focal ischemia of mice. J Cereb Blood Flow Metab 2006;26:402-413.

110. Sehara Y, Hayashi T, Deguchi K, et al. Decreased focal inflammatory response by G-CSF may improve stroke outcome after transient middle cerebral artery occlusion in rats. J Neurosci Res 2007;85:2167-2174.

111. Gibson CL, Jones NC, Prior MJ, Bath PM, Murphy SP. G-CSF suppresses edema formation and reduces interleukin-1beta expression after cerebral ischemia in mice. J Neuropathol Exp Neurol 2005;64:763-769.

112. Taguchi A, Wen Z, Myojin K, et al. Granulocyte colonystimulating factor has a negative effect on stroke outcome in a murine modelwa. Eur J Neurosci 2007;26:126-133.

113. Zhao LR, Berra HH, Duan WM, et al. Beneficial effects of hematopoietic growth factor therapy in chronic ischemic stroke in rats. Stroke 2007;38:2804-2811.

114. Matchett GA, Calinisan JB, Matchett GC, Martin RD, Zhang JH. The effect of granulocyte-colony stimulating factor in global cerebral ischemia in rats. Brain Res 2007;1136:200-207.

115. Schäbitz WR, Laage R, Vogt Gerhard, et al. AXIS. A trial of intravenous granulocyte colony-stimulating factor in acute ischemic stroke. Stroke 2010;41:2545-2551.

116. Shyu WC, Lin SZ, Lee CC, Liu DD, Li H. Granulocyte colonystimulating factor for acute ischemic stroke: a randomized controlled trial. CMAJ 2006;174:927-933.

117. Sprigg N, Bath PM, Lian Zhao, et al. Granulocyte-colong stimulating factor mobilizes bone marrow stem cells in patients with subacute ischemic stroke: The stem cell trial of recovery enhancement after stroke (STEMS) pilot randomized, controlled trial. Stroke 2006;37:2979-2983.

118. Zhang JJ, Deng M, Zhang Y, et al. A short-term assessment of recombinant human granulocyte colony-stimulating factor (RHG-CSF) in treatment of acute cerebral infarction. Cerebrovasc Dis 2006;21(suppl 4):143-144.

119. Kennedy EP. The synthesis of cytidine diphosphate choline, cytidine diphosphate ethanolamine, and related compounds. J Biol Chem 1956;222:185-191.

120. Adibhatla RM, Hatcher JF. Citicoline mechanisms and clinical efficacy in cerebral ischemia. J Neurosci Res 2002;70:133139.

121. Tovarelli G, DeMedio G, Dorman R, Piccinin G, Horrocks L, Porcellati G. Effects of cytidine diphosphate choline (CDPcholine) on ischemia-induced alteration of brain lipid in the gerbil. Neurochem Res 1981;6:821-833.

122. Weiss GB. Metabolism and actions of CDP-choline as an endogenous compound and administered exogenously as citicoline. Life Sci 1995;56:637-660.

123. Secades JJ. CDP-choline: updated pharmacological and clinical review. Methods Find Exp Clin Pharmacol 2002;24 (suppl 2):1-56.

124. Krupinski J, Ferrer I, Barrachina M, Secades JJ, Mercadal J, Lozano R. CDP-choline reduces pro-caspase and cleaved caspase-3 expression, nuclear fragmentation, and specific PARP-cleaved products of caspase activation following middle cerebral artery occlusion in the rat. Neuropharmacology 2002;42:846-854.

125. Ovbiagele B, Kidwell CS, Starkman S, Saver JL. Neuroprotective agents for the treatment of acute ischemic stroke. Curr Neurol Neurosci Rep 2003;3:9-20.

126. Rao AM, Hatcher JF, Dempsey RJ. Does CDP-choline modulate phospholipase activities after transient forebrain ischemia? Brain Res 2001;893:268-272. 
127. Andersen M, Overgaard K, Meden P, et al. Effects of citicoline combined with thrombolytic therapy in a rat embolic stroke model. Stroke 1999;30:1464-1471.

128. Shuaib A, Yang Y, Li Q. Evaluating the efficacy of citicoline in embolic ischemic stroke in rats: neuroprotective effects when used alone or in combination with urokinase. Exp Neurol 2000;161:733-739.

129. Leciñana LAS, Gutirrez M, Roda JM, Carceller F, Diez-Tejedor E. Effect of combined therapy with thrombolysis and citicoline in a rat model of embolic stroke. J Clin Neurosci 2006;247:121-129.

130. Sahin S, Alkan T, Temel SG, Tureyen K, Tolunay S, Korfali E. Effects of citicoline used alone and in combination with mild hypothermia on apoptosis induced by focal cerebral ischemia in rats. J Clin Neurosci 2010;17:227-231.

131. Tazaki Y, Sakai F, Otomo E, et al. Treatment of acute cerebral infarction with a choline precursor in a multicenter double-blind placebo-controlled study. Stroke 1988;19:211-216.

132. Clark WM, Wechsler LR, Sabounjian LA, Schwiderski UE. A phase III randomized efficacy trial of $2000 \mathrm{mg}$ citicoline in acute ischemic stroke patients. Neurology 2001;57:1595-1602.

133. Davalos A, Castillo J, Alvarez-Sabin J, et al. Oral citicoline in acute ischemic stroke: an individual patient data pooling analysis of clinical trials. Stroke 2002;33:2850-2857.

134. Ovbiagele B, Kidwell CS, Starkman S, Saver JL. Potential role of neuroprotective agents in the treatment of patients with acute ischemic stroke. Curr Treat Options Cardiovasc Med 2003;5:441-449.

135. Warach SHK. Dose dependent reduction in infarct growth with citicholine treatment: evidence of neuroprotection in human stroke? Stroke 2002;33:354.

136. Cramer SC. Functional imaging in stroke recovery. Stroke 2004;35:2695-2698.

137. Evans MJ, Kaufman MH. Establishment in culture of pluripotential cells from mouse embryos. Nature 1981;292:154-156.

138. Pollard S, Conti L, Smith A. Exploitation of adherent neural stem cells in basic and applied neurobiology. Regen Med 2006;1:111-118.

139. Reubinoff BE, Pera MF, Fong CY, Trounson A, Bongso A. Embryonic stem cell lines from human blastocysts: somatic differentiation in vitro. Nat Biotechnol 2000;18:399-404.

140. Thomson JA, Itskovitz-Eldor J, Shapiro SS, et al. Embryonic stem cell lines derived from human blastocysts. Science 1998;282:1145-1147.

141. Hoehn M, Kustermann E, Blunk J, et al. Monitoring of implanted stem cell migration in vivo: a highly resolved in vivo magnetic resonance imaging investigation of experimental stroke in rat. Proc Natl Acad Sci USA 2002;99:1626716272 .

142. Erdo F, Buhrle C, Blunk J, et al. Host-dependant tumorigenesis of embryonic stem cell transplantation in experimental stroke. $\mathrm{J}$ Cereb Blood Flow Metab 2003;23:780-785.

143. Takahashi K, Yamanaka S. Induction of pluripotent stem cells from mouse embryonic and adult fibroblast cultures by defined factors. Cell 2006;126:663-676.

144. Takahashi K, Tanabe K, Ohnuki M, et al. Induction of pluripotent stem cells from adult human fibroblasts by defined factors. Cell 2007;131:861-872.

145. Yu J, Vodyanik MA, Smuga-Otto K, et al. Induced pluripotent stem cell lines derived from human somatic cells. Science 2007;318:1917-1920.

146. Jiang Q, Zhang ZG, Ding GL, et al. Investigation of neural progenitor cell induced angiogenesis after embolic stroke in rat using MRI. Neuroimage 2005;28:698-707.

147. Li L, Jiang Q, Zhang L, et al. Ischemic cerebral tissue response to subventricular zone cell transplantation measured by iterative self-organizing data analysis technique algorithm. J Cereb Blood Flow Metab 2006;26:1366-1377.

148. Zhang ZG, Jiang Q, Zhang R, et al. Magnetic resonance imaging and neurosphere therapy of stroke in rat. Ann Neurol 2003;53:259-263.

149. Hicks AU, Hewlett K, Windle V, Chernenko, et al. Enriched environment enhances transplanted subventricular zone stem cell migration and functional recovery after stroke. Neuroscience 2007;146:31-40.

150. Kameda M, Shingo T, Takahashi K, et al. Adult neural stem and progenitor cells modified to secrete GDNF can protect, migrate and integrate after intracerebral transplantation in rats with transient forebrain ischemia. Eur J Neurosci 2007;26:1462-1478.

151. Bianco P, Robey G. Skeletal stem cells. In Lanza R, ed: Handbook of Stem Cells, 1st ed. San Diego: Elsevier Academic Press, 2004:415-4125

152. Chen J, Li Y, Wang L, Lu M, Zhang X, Chopp M. Therapeutic benefit of intracerebral transplantation of bone marrow stromal cells after cerebral ischemia in rats. J Neurol Sci 2001;189:49-57.

153. Chen J, Li Y, Wang L, et al. Therapeutic benefit of intravenous administration of bone marrow stromal cells after cerebral ischemia in rats. Stroke 2001;32:1005-1011.

154. Li Y, Chen J, Wang L, Lu M, Chopp M. Treatment of stroke in rat with intracarotid administration of marrow stromal cells. Neurology 2001;56:1666-1672.

155. Borlongan CV, Evans A, Yu G, Hess DC. Limitations of intravenous human bone marrow CD133+ cell grafts in stroke rats. Brain Res 2005;1048:116-122.

156. Chen J, Sanberg PR, Li Y, et al. Intrvenous administration of human umbilical cord blood reduces behavioral deficits after stroke in rats. Stroke 2001;32:2682-2688.

157. Xiao J, Nan Z, Morooka Y, Low WC. Transplantation of a novel cell line population of umbilical cord blood stem cells ameliorates neurological deficits associated with ischemic brain injury. Stem Cells Dev 2005;14:722-733.

158. Brenneman M, Sharma S, Harting M, et al. Autologous bone marrow mononuclear cells enchance recovery after acute ischemic stroke in your and middle-aged rats. J Cereb Blood Flow Metab 2010;30:140-149.

159. Jiang Y, Jahagirdar BN, Reinhardt RL, et al. Pluripotency of mesenchymal stem cells derived from adult marrow. Nature 2002;418:41-49.

160. Dar A, Kollet O, Lapidot T. Mutual, reciprocal SDF-1/CXCR4 interactions between hematopoietic and bone marrow stromal cells regulate human stem cell migration and development in NOD/SCID chimeric mice. Exp Hematol 2006;34:967-975.

161. Yoon YS, Wecker A, Heyd L, et al. Clonally expanded novel multipotent stem cells from human bone marrow regenerate myocardium after myocardial infarction. J Clin Invest 2005;115:326-338.

162. Kucia M, Reca R, Campbell FR, et al. A population of very small embryonic-like (VSEL) CXCR4(+)SSEA-1(+)Oct-4+ stem cells identified in adult bone marrow. Leukemia 2006;20:857-869.

163. Tang Y, Yasubara T, Hara K, et al. Transplantation of bonemarrow derived stem cells: a promising therapy for stroke. Cell Transplant 2007;16:159-169.

164. Zhao LR, Duan WM, Reyes M, Keene CD, Verfaillie CM, Low WC. Human bone marrow stem cells exhibit neural phenotypes and ameliorate neurological deficits after grafting into the ischemic brain of rats. Exp Neurol 2002;174:11-20.

165. Doucette JR. The glial cells in nerve fiber layer of the rat olfactory bulb. Anat Rec 1984;210:385-391.

166. Shyu WC, Liu DD, Lin SZ, et al. Implantation of olfactory ensheathing cells promotes neuroplasticity in murine models of stroke. J CLin Invest 2008;118:2482-2495. 
167. Bliss T, Guzman R, Daadi M, Steinberg GK. Cell transplantation therapy for stroke. Stroke 2007;38:817-826.

168. Andres RH, Guzman R, Ducray AD, et al. Cell replacement therapy for intracerebral hemorrhage. Neurosurg Focus 2008;24: E16.

169. Englund U, Bjorklund A, Wictorin K, Lindvall O, Kokaia M. Grafted neural stem cells develop into functional pyramidal neurons and integrate into host cortical circuitry. Proc Natl Acad Sci USA 2002;99:17089-17094.

170. Wernig M, Benninger F, Schmandt $T$, et al. Functional integration of embryonic stem cell-derived neurons in vivo. $\mathrm{J}$ Neurosci 2004;24:5358-5368.

171. Shyu WC, Lee YJ, Liu DD, Lin SZ, Li H. Homing genes, cell therapy and stroke. Front Biosci 2006;11:899-907.

172. Borlongan CV, Hadman M, Sanberg CD, Sanberg PR. Central nervous system entry of peripherally injected umbilical cord blood cells is not required for neuroprotection in stroke. Stroke 2004;35:2385-2389.

173. Kuruzomi K, Nakamura K, Tamiya T, et al. Mesenchymal stem cells that produce neurotrophic factors reduce ischemic damage in the rat middle cerebral artery occlusion model. Mol Ther 2005;11:96-104.

174. Xiao J, Nan Z, Motooka Y, Low WC. Transplantation of a novel cell line population of umbilical cord blood stem cells ameliorates neurological deficits associated with ischemic brain injury. Stem Cells Dev 2005;14:722-733.

175. Chen J, Zhang ZG, Li Y, et al. Intravenous administration of human bone marrow stromal cells induces angiogenesis in the ischemic boundary zone after stroke in rats. Circ Res 2003;92:692-699

176. Taguchi A, Soma T, Tanaka H, et al. Administration of CD34+ cells after stroke enhances neurogenesis via angiogenesis in a mouse model. J Clin Invest 2004;114:330-338.

177. Shen LH, Li Y, Chen J, et al. Intracarotid transplantation of bone marrow stromal cells increases axon-myelin remodeling after stroke. Neuroscience 2006;137:393-399.

178. Ishibashi S, Sakaguchi M, Kuroiwa T, et al. Human neural stem/ progenitor cells, expanded in long-term neurosphere culture, promote functional recovery after focal ischemia in Mongolian gerbils. J Neurosci Res 2004;78:215-223.

179. Vendrame M, Gemma C, de Mesquita D, et al. Antiinflammatory effects of human cord blood cells in a rat model of stroke. Stem Cells Dev 2005;14:595-604.

180. Johansson BB. Brain plasticity and stroke rehabilitation. Stroke 2000;31:223-230.

181. Grote HE, Hannan AJ. Regulators of adult neurogenesis in the healthy and diseased brain. Clin Exp Pharmacol Physiol 2007;34:533-545.

182. Parent JM, Vexler ZS, Gong C, Derugin N, Ferriero DM. Rat forebrain neurogenesis and striatal neuron replacement after focal stroke. Ann Neurol 2002;52:802-813.

183. Arvidsson A, Collin T, Kirik D, Kokaia Z, Lindvall O. Neuronal replacement from endogenous precursors in the adult brain after stroke. Nat Med 2002;8:963-970.

184. Chopp M, Li Y. Treatment of stroke and intracerebral hemorrhage with cellular and pharmacological restorative therapies. Acta Neurochir 2008;5(suppl 1):79-83.

185. Johnston RE, Dillon-Carter O, Freed WJ, Borlongan CV. Trophic factor secreting kidney cell lines: in vitro characterization and functional effects following transplantation in ischemic rats. Brain Res 2001;900:268-276.

186. Boncoraglio GB, Bersano A, Candelise L, Reynolds BA, Parati EA. Stem cell transplantation for ischemic stroke. Cochrane Database of Systematic Reviews 2010, Issue 9. Art. No.: CD007231. doi:10.1002/14651858.CD007231
187. Bang OY, Lee JS, Lee PH, Lee G. Autologous mesenchymal stem cell transplantation in stroke patients. Ann Neurol 2005;57:874-882.

188. Savitz SI, Dinsmore J, Wu J, Henderson GV, Stieg P, Caplan LR. Neurotransplantation of fetal porcine cells in patients with basal ganglia infarcts: a preliminary safety and feasibility study. Cerebrovasc Dis 2005;20:101-107.

189. Kondziolka D, Steinberg GK, Wechsler L, et al. Neurotransplantation for patients with subcortical motor stroke: a phase 2 randomized trial. J Neurosurg 2005;103:38-45.

190. Kondziolka D, Wechsler L, Goldstein S, et al. Transplantation of cultured human neuronal cells for patients with stroke. Neurology 2000;55:565-569.

191. The STEPS Participants. Stem Cell Therapies as an Emerging Paradigm in Stroke (STEPS). Bridging basic and clinical science for cellular and neurogenic factor therapy in treating stroke. Stroke 2009;40:510-515.

192. Jin K, Sun Y, Xie L, et al. Comparison of ischemia-directed migration of neural precursor cells after intrastriatal, intraventricular, or intravenous transplantation in the rat. Neurobiol Dis $2005 ; 18: 366-374$.

193. Schrepfer S, Deuse T, Reichenspurner H, Fischbein MP, Robbins RC, Pelletier MP. Stem cell transplantation: the lung barrier. Transplant Proc March 2007;39:573-576.

194. Fischer UM, Harting MT, Jiminez F, et al. Pulmonary passage is a major obstacle for intravenous stem cell therapy: the pulmonary first-pass effect, stem cells and development 2009;18:683-691.

195. Kelly S, Bliss TM, Shah AK, et al. Transplanted human fetal neural stem cells survive, migrate, and differentiate in ischemic rat cerebral cortex. Proc Natl Acad Sci USA 2004;101:11839-11844.

196. Modo M, Mellodew K, Cash D, et al. Mapping transplanted stem cell migration after a stroke: a serial, in vivo magnetic resonance imaging study. Neuroimage 2004;21:311-317.

197. Savitz SI, Misra V. Launching intravenous bone marrow cell trials for acute stroke. Regen Med 2009;4:639-641.

198. Brenneman M, Sharma S, Harting M, et al. Autologous bone marrow mononuclear cells enhance recovery after acute ischemic stroke in young and middle-aged rats. J Cereb Blood Flow Metab 2010;30:140-149

199. The university of Texas Health Science Center, Houston. Safety/ feasibility of autologous mononuclear bone marrow cells in stroke patients. In: ClinicalTrials.gov [Internet]. Bethesda (MD): National Library of Medicine (US). 2000- [2011 May 06]. Available from: http://clinicaltrials.gov/show/NCT00859014: NLM Identifier: NCT00859014.

200. University Hospital, Grenoble. Intravenous stem cells after ischemic stroke. In: ClinicalTrials.gov [Internet]. Bethesda (MD): National Library of Medicine (US). 2000-[2011 May 06]. Available from: http://clinicaltrials.gov/show/ NCT00875654: NLM Identifier: NCT00875654.

201. Hospital Universitario Central de Asturias. Autologous bone marrow stem cells in middle cerebral artery acute stroke treatment. In: ClinicalTrials.gov [Internet]. Bethesda (MD): National Library of Medicine (US). 2000- [2011 May 06]. Available from: http://clinicaltrials.gov/show/NCT00761982: NLM Identifier: NCT00761982.

202. Federal University of Rio de Janeiro. Safety study of autologous stem cell transplantation for patients with ischemic stroke. In: ClinicalTrials.gov [Internet]. Bethesda (MD): National Library of Medicine (US). 2000- [2011 May 06]. Available from: http:// clinicaltrials.gov/show/NCT00473057: NLM Identifier: NCT00473057.

203. Imperial College, London. Autologous bone marrow stem cells in ischemic stroke. In: ClinicalTrials.gov [Internet]. Bethesda 
(MD): National Library of Medicine (US). 2000-[2011 May 06]. Available from: http://clinicaltrials.gov/show/NCT00535197: NLM Identifier: NCT005350197.

204. ReNeuron Limited. Pilot investigation of stem cells in stroke. In: ClinicalTrials.gov [Internet]. Bethesda (MD): National Library of Medicine (US). 2000- [2011 May 06]. Available from: http:// clinicaltrials.gov/show/NCT01151124: NLM Identifier: NCT01151124.

205. San Bio, Inc. A study of modified stem cell SD623 in stable ischemic stroke. In: ClinicalTrials.gov [Internet]. Bethesda (MD): National Library of Medicine (US). 2000-[2011 May 06]. Available from: http://clinicaltrials.gov/show/ NCT01287936: NLM Identifier: NCT01287936.

206. Stemedica Cell Technologies, Inc. A study of allogenic mesenchymal bone marrow cells in subjects with ischemic stroke. In:
ClinicalTrials.gov [Internet]. Bethesda (MD): National Library of Medicine (US). 2000- [2011 May 06]. Available from: http:// clinicaltrials.gov/show/NCT01297413: NLM Identifier: NCT01297413.

207. Aldagen. Study of ALD 401 via intracarotid infusion in ischemic stroke subjects. In: ClinicalTrials.gov [Internet]. Bethesda (MD): National Library of Medicine (US). 2000-[2011 May 06]. Available from: http://clinicaltrials.gov/show/NCT01273337: NLM Identifier: NCT01273337.

208. China Medical University hospital. Evaluation of Safety, Feasibility and Treatment Potential for Old Stroke Patients Using Intracerebral Implantation of Olfactory Ensheathing Cells. In: ClinicalTrials.gov [Internet]. Bethesda (MD): National Library of Medicine (US). 2000- [2011 May 06]. Available from: http://clinicaltrials.gov/ show/NCT01327768: NLM Identifier: NCT01327768. 